\title{
Kurutulmuş alglerin besin değeri ve gıda olarak kullanımı
}

\section{The nutritional value of dried algae and the usage as food}

\author{
Seda Oğur \\ Bitlis Eren Üniversitesi, Mühendislik Mimarlık Fakültesi, Gıda Mühendisliği Bölümü, Rahva Yerleşkesi, 13000 Merkez-Bittlis \\ sdogur@beu.edu.tr
}

Oğur, S. (2016). The nutritional value of dried algae and the usage as food (in Turkish with English abstract). Ege Journal of Fisheries and Aquatic Sciences, 33(1): 67-79. doi: 10.12714/egejfas.2016.33.1.10

Öz: Latince "deniz otu" anlamına gelen, deniz yosunları olarak da adlandıılan algler birçok ülkede gıda, tarım, tıp, eczacılık, kozmetik, biyoteknoloji, enerji, kimya sanayi gibi pek çok alanda ve farklı amaçlarla kullanılmaktadır. Uzak Doğu ve Güney Asya ülkelerinde özelliklerine göre farklı şekillerde kurutulan denizel makroalglerin en önemlileri: Nori, aonori, kombu, hiziki, wakame, mozuku, deniz üzümü, dulse, Irlanda yosunu, kanatı kelpi, ogo, ogonori ve carola'dır. Güneşte veya yapay kurutucularda kurutulan alglerden daha sonra değişik salatalar, yemekler, çorbalar, soslar ve çaylar hazırlanabilmektedir. Bu derlemede besinsel açıdan oldukça yüksek değere sahip, fakat yeterince önem gösterilmeyen denizel makroalglerin kurutulma yöntemleri, besin değerleri ve kurutulmuş alglerden üretilen farklı gıdalar hakkında bilgi verilmeye çalışımıştır.

Anahtar kelimeler: Kurutulmuş algler, besin değeri, nori, kombu, hiziki, wakame

Abstract: Algae, latin means sea grass, also termed as seaweed, are used in many areas such as food, agriculture, medicine, pharmacy, cosmetics, biotechnology, energy, chemical industry and for different purposes in many countries. The most important of algae, dried differently according to their attributes in Far East and South Asia countries, are; nori, aonori, kombu, hiziki, wakame, mozuku, sea grapes, dulse, Irish moss, winged kelp, ogo, ogonori and carola. Various salads, meals, soups, sauces and teas are prepared from algae dried in the sun or artificial dryers. In this review was aimed to give information about drying method, nutritional value of marine macroalgae and different foods made from dried algae has a very high nutritional value, but not shown enough importance.

Keywords: Dried algae, nutritional value, nori, kombu, hiziki, wakame

\section{Gíriş}

Algler, birçok sucul canlının besin kaynağın oluşturmalarının yanında tüm dünyanın ihtiyacı olan fotosentetik karbon intiyacının üçte ikisini üretmeleri ve tüm ekosistemin bütünlüğünün korunması açısından oldukça önemlidirler (Özdemir ve Erkmen, 2013).

Birkaç yüzyıldır, Çin, Japonya ve Kore Cumhuriyeti'nde deniz yosunlarının gıda olarak geleneksel bir kullanımı vardır. Bu ülkelerdeki insanların dünyanın her tarafına göç etmesiyle birlikte bu gelenek de onlarla birlikte taşınmış ve bugün deniz yosunlarının tüketimine alışmış olan ülke sayısı artmıştır. Menünün ekzotik bir bileşeni olarak kabul edilse de; deniz yosununu Avrupa mutfağına tanıtmak için Fransa'da güçlü bir hareket vardır. Deniz yosunları Japon topluluklarının daha çok olduğu Kaliforniya, Hawai gibi bölgelerde daha fazla kabul görmüştür. Amerika Birleşik Devletleri ve Kanada'nın doğu kıyısında, Maine, New Brunscwick ve Nova Scotia çevresinde, bazı şirketler özellikle insan tüketimi için kıyıda deniz yosunları yetiştirmekte ve Japonya'ya inraç etmektedir. İrlanda ve Kuzey İrlanda diyetin geleneksel bir parçası olan deniz yosunlarına yoğun ilgi göstermektedir. Tüketicilerin bugünkü trendi organik olarak yetiştirilmiş gıdalar ve doğal gıdalar olduğu için deniz yosunları oldukça kabul görmektedir (McHugh, 2003).

Alglerin özellikle endüstriyel amaçlı kullanımları mikro ve makro algler düzeyinde farklııklar göstermektedir. Mikroalglerin üretiminde (bakteriyel kaynaklarda olduğu gibi) kontaminasyon riski ve hasatlarında yaşanan zorluklar nedeniyle endüstriyel üretimde hammadde olarak daha çok denizel makroalgler (Porphyra, Laminaria, Gracilaria gibi) tercih edilmektedir (Özdemir ve Erkmen, 2013).

Yapılan bir araştırmada Japonya'da kültürü yapılan su ürünlerinin oranlarına bakıldığında en fazla payı \%58.3'lük bir oranla algler alırken, ikinci sırada kabuklu deniz hayvanları, üçüncü sırada ise deniz balıkları yer almıştır (Kocataş, 2005).

Algler sanayinin hemen hemen her alanında kullanılmaktadır. Özellikle Uzak Doğu ve Güney Asya ülkelerinde besin maddesi olarak, ayrıca, tıp, eczacılık ile kozmetik sanayiinde, tarımda gübre yapımında geniş bir 
kullanım alanı olan algler, doğal olarak toplanmalarının yanısıra, kültürleri de yapılmakta ve denizlerde de karalar gibi ekilip biçilmektedir. Algler, brom, iyot, organik asitler, monosakkaritler, polisakkaritler, agar, aljinik asit, steroller, proteinler ve vitaminler içermektedirler (Atay, 1984).

Alglerden ilk olarak kozmetik sanayiinde renk maddesi olarak, Roma imparatorluğunda Virjil ve Heros zamanında yararlanılmıştır. Alglerin bilinen en eski kullanım sahası gübre yapımı olup, en çok Uzak Doğu'da kullanılmıştır. Çağımız alg endüstrisinde iyot ve brom bugün yan ürün durumundadır (Cirik, 1981).

Çin'de makroalglerin insan gıdası olarak kullanımının 2500 yıl öncesine dayandığı tahmin edilmektedir (Tseng, 1981). Son yıllarda alg ürünleri tüketiminin Avrupa ülkelerinde de arttığı belirtilmektedir (Dawczynski vd., 2007). Yaklaşık 221 makroalg ticari olarak değerlendirilmekte ve bunların \%65'i insan gıdası olarak kullanılmaktadır (Zewke-White ve Ohno, 1999).

Makroalglerin katkı maddesi olarak kullanımı ve hatta tıp alanında kullanımı giderek artmaktadır (Wong ve Cheung, 2000).

Ekonomik öneme sahip deniz algleri üç grup altında toplanmaktadır: Yeşil algler (Cholorophyceae), Kahverengi algler (Phaeophyceae), Kırmızı algler (Rhodophyceae). Agar, Uzak Doğu'da üretilen ilk kırmızı alg ürünüdür ve Avrupa'da sonradan tanınmışıı. Agar gibi kırmızı alglerden elde edilen bir ürün olan karragenan, Avrupa sahillerinde çok eski yıllardan beri marmelatları katılaştırıcı ve benzeri işlerde kullanıımıştır. Daha sonra ise ekstraksiyon yolu ile elde edilen karregananın kullanııma sahaları ve önemi oldukça artmıştır (Jensen, 1966).

Kırmızı alglerin yanında, kahverengi alglerin de büyük değeri bulunmaktadır. Kahverengi alglerden elde edilen, önemli ürünlerin başında aljinik asit ve aljinatlar gelmektedir. Aljinik asit ve aljinatların Amerika'daki üretimi 1929 yılında başlamış ve endüstri kolu olarak gelişmiştir (Myklestad, 1963).

Alg endüstrisinin kaynak sorunu ile karşılaşmaması için, denizde doğal olarak üreyen alglerden faydalanmanın yanında, bu bitkilerin kültürlerinden de yararlanma yoluna gidilmiştir (Cirik, 1981).

Batı Avrupa ülkeleri ile ABD'de zorunlu periyotlar dışında algler direkt olarak yenmese bile, ekstraksiyonları yapılarak mutfakta tüketilmiştir (Soeder, 1976).

Alglerin Uzakdoğu ülkelerinde, özellikle Japonya'da uzun yıllardan beri tüketildiği bilinmektedir. Kahverengi ve kırmızı algler, yeşil alglerden daha baskındır. Laminaria, Undaria ve Hizikia türleri başlıca kahverengi algler olup, genellikle kurutulmuş olarak satılmaktadır. Deniz algleri taze olarak (salata şeklinde), kurutulmuş olarak, pişirilerek (yemek, çorba, sos şeklinde) değerlendirilmektedir. Japonya'da hazır besin maddesi olarak asoksanari, amonani, kanten, kombu gibi isimlerle satılmakta, ayrıca çay olarak da içilmektedir (Soeder, 1976). Ülkemiz denizlerinde bu amaçlar için kullanılabilecek Ulva, Porphyra, Gelidium, Rhodymenia, Laurencia türü algler bulunmaktadır (Kaba ve Çağlak, 2006).

Denizlerimizde dağılım gösteren, bileşimleri yönünden ekonomik önem taşıyan türler üzerinde yapılan biyokimyasal araştırmalarda, bu bitkilerden aljinik asit, agar, karragenan, vitamin $B_{12}$, bazı organik asitler ve selüloz elde edilmiştir (Güven vd., 1991). Ayrıca hayvan yemi elde edilebilecek, gübre olarak kullanılabilecek, kozmetikte faydalanılabilecek türlerin kıyılarımızda varlığı saptanmıştır. Algler güzellik enstitüleri tarafından Türkiye'de oldukça yaygın olarak kullanılmakta, alg içeren kozmetik ürünlerinin çeşidi artmaktadır (Atay, 1978).

Alglerin karbonhidrat, protein, lipid, yağ asitleri, gliserol, doğal pigmentler (beta-karoten, astaksantin, ksantofil, fikobilin) ve amino asitlerce (Durmaz vd., 2002) çok zengin oldukları, ayrıca mineral, vitamin, polisakkaritler (Arasaki ve Arasaki, 1983) ve polifenoller gibi antibakteriyel, antifungal ve antiviral özelliğe sahip biyoaktif maddeler (Chandini vd., 2008) içerdikleri tespit edilmiştir. Algler antioksidan vitamin ve pigmentlerin yanısıra çoklu doymamış yağ asitlerinin de zengin bir kaynağıdır (Gökpınar vd., 2001).

Ülkemizin üç yanı denizlerle çevrili olmasına karşın, makroalglerin kullanım alanları oldukça sınırlı düzeydedir. Türkiye kıyılarında dağılım gösteren makroalglerin kimyasal içeriği ve kullanım olanakları konusundaki çalışmalar ise giderek artış göstermiştir (Çetingül ve Güner, 1996; Bilgin ve Ertan, 2002; Dere vd., 2003; Kaykaç vd. 2008; Polat ve Özoğul, 2008; Polat ve Özoğul, 2009). Nüfusun hızla çoğaldığı, açlık sorununun giderek büyüdüğü günümüzde; besin yönünden önemli bir kaynak olan alglere, gıda sektöründe gereken önemin verilmesi oldukça faydalı olacaktır.

Bu derlemede denizel makroalglerin kurutulma yöntemleri, besin değerleri ve kurutulmuş alglerden üretilen farklı gıdalardan bahsedilmiştir.

Nori veya Mor Laver (Porphyra spp.): Japonya, Kore Cumhuriyeti ve Çin'de yetiştiriciliği yapılan nori, Japonya'da listenin başında yer almaktadır (Şekil 1). İnsan besini olarak kullanılan makroalglerden mor laver, dünyada yaklaşık 50 türü içeren, büyük taksonomik gruplardan oluşur ve 20 türü Japonya'da bulunur. Porphyra ürününün Japon yetiştiriciliği yaklaşık 400000 ton(yaş)/yıl'dır ve bu boyutları $20 \times 20 \mathrm{~cm}$, ağırlığı $3.5-4 \mathrm{~g}$ olan yaklaşık 10 milyar nori yaprağına işlenir (Nisizawa, 1987).

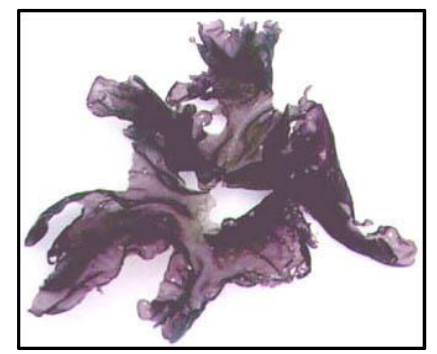

Şekil 1. Porphyra umbilicalis (numune genişliği yaklaşık $20 \mathrm{~cm}$ ) (Nisizawa, 1987)

Figure 1. Porphyra umbilicalis (width of specimen is about $20 \mathrm{~cm}$ ) (Nisizawa, 1987) 
Yaş Porphyra'nın norinin kuru yapraklarına işlenmesi kâğıt yapım işleminin bir adaptasyonuna benzer şekilde oldukça mekanize hale gelmiştir. Kış sezonunda yetişen mor laver, kültür tarlalarından mekanik olarak hasat edilir. Deniz suyu ile yıkanarak kirleticiler ve epifitlerden arındırıır, küçük parçalar halinde kıyılır ve bir bulamaç halinde karıştııılır. Daha sonra hasırlar veya çerçeveler üzerinde dökülür, suyun fazlası uzaklaştırılır ve hasırlar bir kurutucu boyunca ilerler. Konveyör hızı ve sıcaklığın ayarlanmasıyla $\left(40{ }^{\circ} C^{\prime}\right.$ ye) kuruma oranı dikkatlice kontrol edilir. Yapraklar hasır üzerinden sıyrılır ve satış için on demet halinde paketlenir. Bu ürün kendisini kızartıımış olan "yaki-nori"den ayırmak için "hoshi-nori (kuru laver yaprağı)" olarak isimlendirilir. Yaki-nori önceden kızartılıp kapalı paketlerde satılan, soya sosu, şeker, sake ve baharat karışımı sürelerek kullanılan noridir. Hoshi norinin bir kısmı kavrulmuş veya tatlandırımış laver ürünlerine dönüştürülür. Çabuk çorba, reçel ve şarap gibi nori katkılı yiyecekler piyasaya da sunulmuştur (Şekil 2) (Nisizawa, 1987).

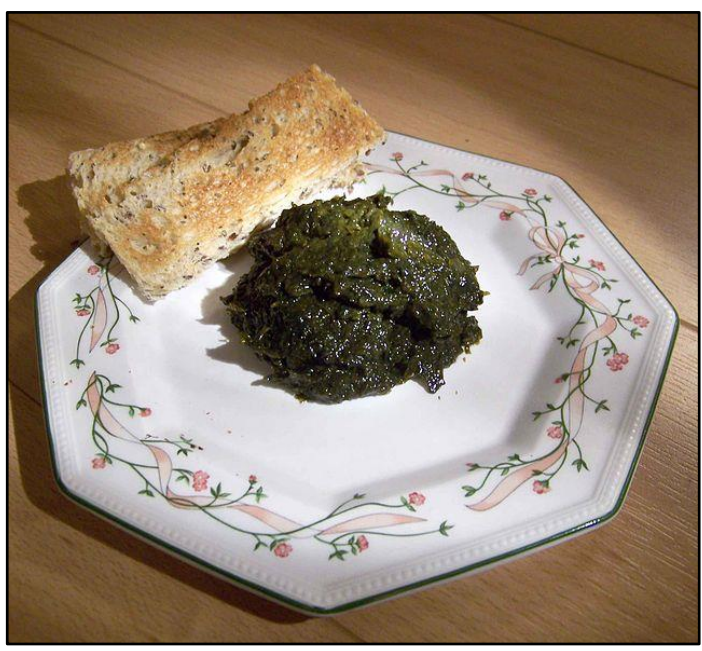

Şekil 2. Laver ve tost (Anonim, 2015a)

Figure 2. Laver and toast (Anonim, 2015a)

Nori, \%30-50 protein içeriği ve bunun da yaklaşık \%75'inin sindirilebilir olması ile en besleyici deniz yosunları arasındadır. Şeker içeriği düşük $(\% 0,1)$ ve $A$ vitamini, $C$ vitamini, niasin ve folik asitin önemli miktarlarına sahip olup, vitamin içeriği oldukça yüksektir (Chapman ve Chapman, 1980). Norinin karakteristik tadı alanin, glutamik asit ve glisin amino asitlerinden oluşmaktadır (Fleurence, 1999).

Hoshi norinin besin değeri, kontrollü koşullar altında imal edildiği takdirde, hemen hemen taze lavere yakındır. Protein içeriği açısından zengin ve yağ içeriği diğer alglerle karşılaştırıldığında nispeten yüksektir (Kanazawa, 1963; Noda, 1971). Hoshi nori vitamin açısından, askorbik asit, özellikle $B_{12}$ vitaminince zengindir (Tablo 1) (Noda vd., 1975).
Tablo 1. Mor laverin (100 g) besin değeri (USDA, 2015)

Table 1. Nutritional value of purple laver (per $100 \mathrm{~g}$ ) (USDA, 2015)

\begin{tabular}{|l|l|}
\hline Enerji & $35 \mathrm{kcal}$ \\
\hline Karbonhidrat & $5.11 \mathrm{~g}$ \\
\hline Diyetsel lif & $0.3 \mathrm{~g}$ \\
\hline Yağ & $0.28 \mathrm{~g}$ \\
\hline Protein & $5.81 \mathrm{~g}$ \\
\hline Su & $85.03 \mathrm{~g}$ \\
\hline A vitamini ekuvalent & $260 \mu \mathrm{g}$ \\
\hline Tiamin $\left(\mathrm{B}_{1}\right)$ & $0.098 \mathrm{mg}$ \\
\hline Riboflavin $\left(\mathrm{B}_{2}\right)$ & $0.446 \mathrm{mg}$ \\
\hline Niasin (B $\left.{ }_{3}\right)$ & $1.470 \mathrm{mg}$ \\
\hline Folat (Bg) & $146 \mu \mathrm{g}$ \\
\hline C vitamini & $39.0 \mathrm{mg}$ \\
\hline E vitamini & $1.00 \mathrm{mg}$ \\
\hline K vitamini & $4.0 \mu \mathrm{g}$ \\
\hline Kalsiyum & $70 \mathrm{mg}$ \\
\hline Demir & $1.80 \mathrm{mg}$ \\
\hline Magnezyum & $2 \mathrm{mg}$ \\
\hline Fosfor & $58 \mathrm{mg}$ \\
\hline Potasyum & $356 \mathrm{mg}$ \\
\hline Sodyum & $48 \mathrm{mg}$ \\
\hline Çinko & $1.05 \mathrm{mg}$ \\
\hline
\end{tabular}

Galler'de laver, geleneksel bir Gal yemeği olan laver ekmeği (bara lafwr veya bara lawr) yapımında kullanılmaktadır. Laver ekmeği yapmak için, deniz yosunu birkaç saat kaynatıır, daha sonra kıyllır ve püre haline getirilir. Jelatinimsi macun bu haliyle satılabilir veya yulaf ezmesine haddelenebilir, genellikle kızartmadan önce yulaf ezmesiyle kaplanır. Laver ekmeği geleneksel olarak Gal kahvaltısının bir parçası olarak pastırma ve cockles ile kızartılarak yenir. Ayrıca, kuzu eti, yengeç, maymun balığı vb. yiyeceklere eşlik edecek bir sos ve laver çorbası (cawl lafwr) yapmak için de kullanılmaktadır. Galler'e ek olarak kuzey Devon'daki Bristol Kanalı genelinde, özellikle Exmoor kıyısı çevresinde, Lynmouth, Combe Martin ve Ilfracombe çevresinde laver ekmeği yenmektedir. Kuzey Devon'da genellikle yulaf ezmesiyle pişirilmez ve "Laver" (layver) olarak adalandırılır (Anonim, 2015a).

Norinin en çok kullanıldığı alan sushidir (Şekil 3). Bir başka metotta, nori kısa bir süre pişirildikten sonra küçük parçalar halinde kesilir ve haşlanmış pirinç ya da şehriyenin üzerine serpilir. Ayrıca soya sosunda kaynatılarak konserve yapılan tsukudani aonori lüks bir yemek olarak bilinir. Norinin başka bir kullanım alanı ise, onigiri adı verilen pirinç sandviçleridir. Nori reçel ve şarap için hammadde olarak kullanılmakta, ürünlere de nori reçeli veya nori şarabı denmektedir. Çin'de nori, çorba yapımında ve kızgın yağda kızartılarak baharatı yiyeceklerin hazırlanmasında kullanılmaktadır (Nisizawa, 1987). 


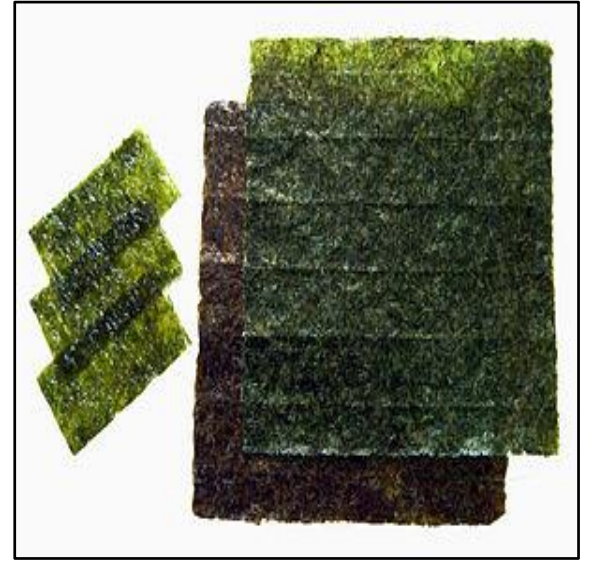

Şekil 3. Nori tabakaları (Anonim, 2015b)

Figure 3. Nori sheets (Anonim, 2015b)
Aonori veya Yeşil Laver (Monostroma spp. ve Enteromorpha spp.): İnsan besini olarak kullanılan bir diğer makroalg Aonori, deniz marulu (Ulva) veya gerçek yeşil laver (Enteromorpha) ve Monostrama gibi çeşitli yeşil deniz yosunları karışımının ticari adıdır (Şekil 4). Bu yeşil yosunlardan Monostrama latissimum ve Enteromorpha prolifera günümüzde Japonya'da ticari amaçlarla yetiştirilmektedir. Kore Cumhuriyeti'nde de Enteromorpha yetiştiriciliğine teşebbüs edilmiştir, fakat sınırlı başarı elde edilmiştir. Monostroma latissimum Japonya'nın güney bölgelerindeki koylarda ve körfezlerde, genellikle üst kıyı bölgesinde doğal olarak oluşmaktadır. Koylarda ve nehir ağızları gibi yerlerde bulunan sığ ve sakin sularda yetiştirilebillir, fakat Porphyra gibi, yüzen salların kullanımıyla derin sularda da büyüyebilir (Nisizawa, 1987).

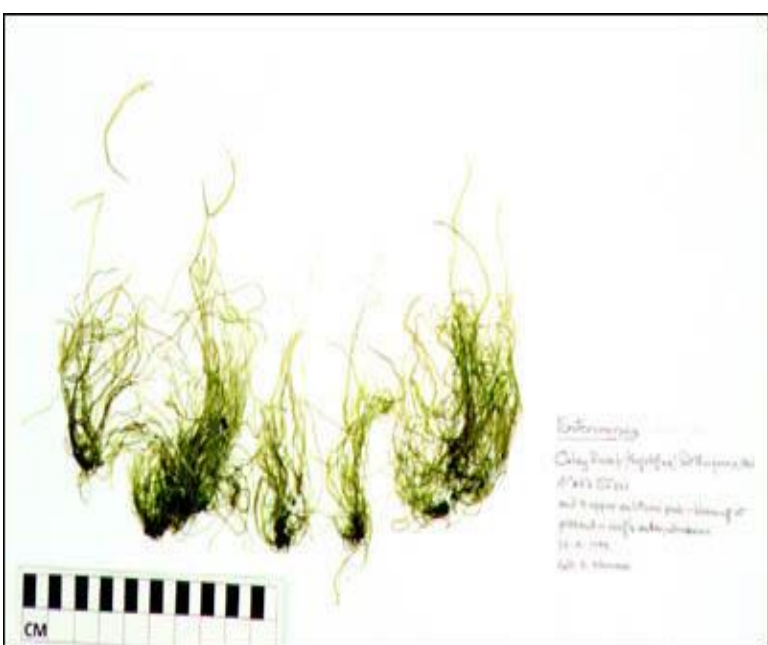

(a)

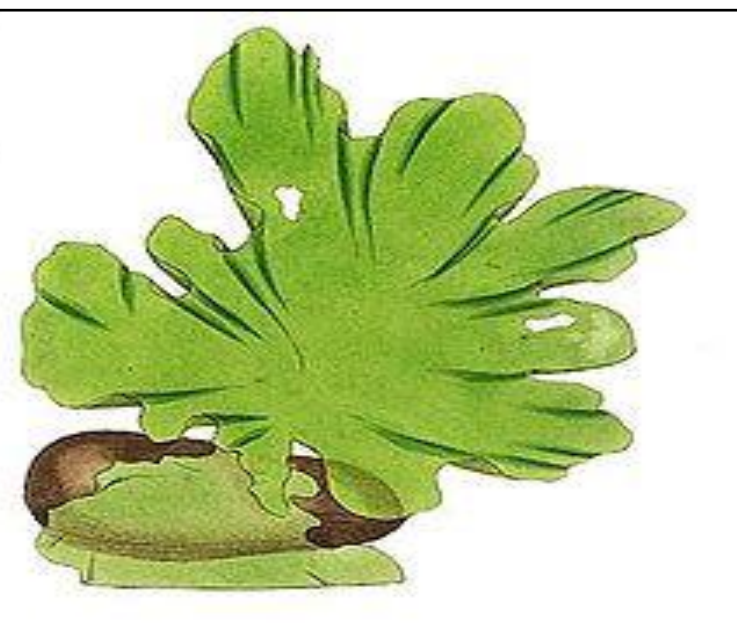

(b)

Şekil 4. a) Enteromorpha intestinalis (Nisizawa, 1987), b) Ulva lattuca (Anonim, 2015c)

Figure 4. a) Enteromorpha intestinalis (Nisizawa, 1987), b) Ulva lattuca (Anonim, 2015c)

Her iki tür Avrupa ve Kuzey Amerika'yı içeren dünyanın diğer kısımlarında da bulunur. Yaklaşık \%20-26 protein, biraz yağ ve \%19-23 mineral madde içermektedirler (Yamamota, 1982). Düşük sodyum, yüksek demir ve kalsiyum içerir. B grubu vitamin içeriği genellikle birçok sebzeden daha yüksektir ve $A$ vitamini de yüksek miktarda bulunmaktadır içeriği de yüksek değerdedir. Doğal kaynaklarda yetişir ve buralardan toplanır, fakat dikkatli şekilde yetiştiriciliğinin yapılmasıyla daha tekdüze ve daha iyi renk (yeşil iyi, koyu yeşil daha iyi) elde edilebilir (Nisizawa, 1987).

Yeşil laver ve Monostroma, hasat edilmesinin hemen ardından içme suyuyla yıkanır, güneşte ya da kurutucuda geniş tepsilerde kurutulur. Flavoru geliştirmek için hafifçe kızartıır. Aonorinin bir kısmı pazara bu formda gelir. Bir kısmı da toz haline getirilir veya küçük parçalar halinde ezilir ve bir garnitür olarak kullanılabilir. Haşlanmış pirinç üzerinde ve çorbalarda çeşni olarak kullanılır. Ayrıca, Monostroma, soya sosu ve şeker ile kaynatılarak konserve olarak işlenir. Kurutulmuş anorinin bir kısmı, şeffaf folyoya sarılmış olarak, pazarda ya da marketlerde satışa sunulur (Nisizawa, 1987).

Kombu veya Haidai (Laminaria japonica): Kombu, Laminaria türünün bir karışımından türetilen kurutulmuş deniz yosununun Japonca ismidir. Bunlar içerisinde $L$. longissima, $L$. japonica, L. angustata, L. coriacea ve $L$. ochotensis bulunmaktadır. Hepsi doğal kaynaklardan, çoğunlukla Hokkaido'nun kuzey adasından toplanmakta; yaklaşık \%10'u Honshu'nun kuzey kıyılarından gelmektedir. Kombu en çok; Laminaria japonica, Laminaria angustata türlerini içerir. Kombu bir enerji kaynağı olarak düşünülmüştür ve yetiştiriciliği başarıyla yapılmaktadır. Çin'de elde edilen kombunun \%32'si aljinat üretiminde hammadde olarak kullanılmaktadır (Nisizawa, 1987).

Haidai, 1920'lerin sonunda Japonya'dan Çin'e kazara tanıtılan bir deniz yosunu olan Laminaria japonica'nın Çince ismidir. Daha önce, Çin bütün intiyacını Japonya ve Kore Cumhuriyeti'nden ithal etmekteyken; sonraları bu deniz yosunu 
Çin'de oldukça fazla yetiştiril hale gelmiştir. Laminaria japonica Kore Cumhuriyeti'nde doğal olarak büyümekte, fakat Koreliler wakame (Undaria pinnatifida)'yi daha çok tercih ettiği için yetiştiriciliği daha az yapılmaktadır (Şekil 5) (Nisizawa, 1987).

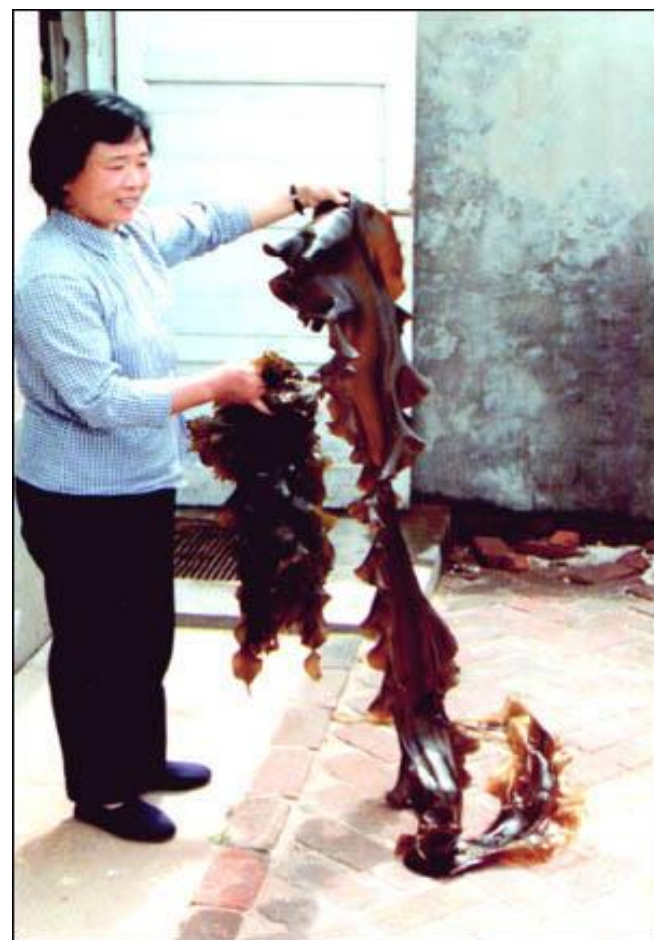

(a)

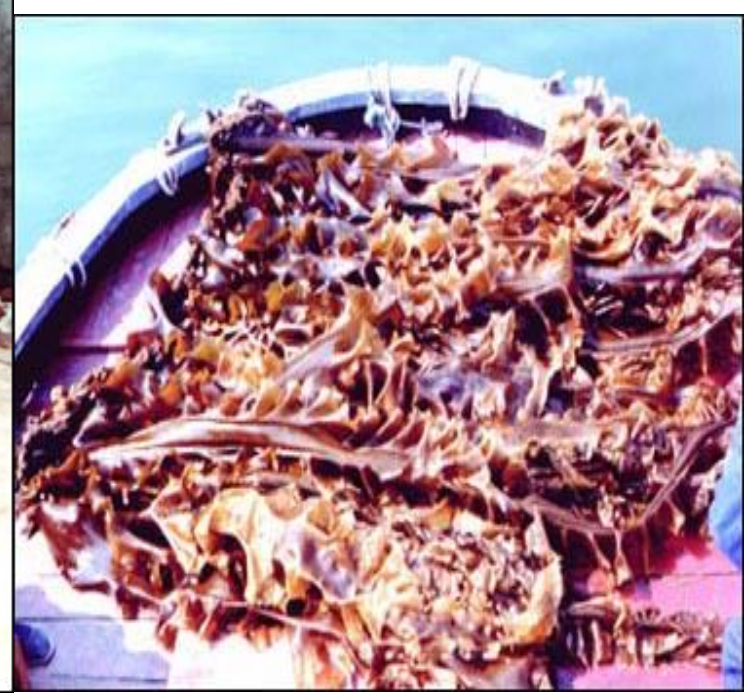

(b)

Sekil 5. Taze Laminaria japonica ve Undaria pinnatifida ((a)'daki daha uzun parça ve (b)) (Nisizawa, 1987)

Figure 5. Fresh Laminaria japonica and Undaria pinnatifida (longer piece on (a) and (b)) (Nisizawa, 1987)

Japonya'da bütün haldeki deniz yosunları deniz suyuyla yıkanır, $1 \mathrm{~m}$ uzunluğundaki parçalara kesilir, katlanır ve genelikle güneşe serilerek, toprak üzerinde çakı taşları ile kaplı olarak kurutulur ve daha sonra balyalar halinde paketlenir (Şekil 6). Ancak, gerekirse bir kurutucuda da kurutulabilir. Bu ürüne "suboshi kombu" denir ve yerel balıkçlık kooperatifine teslim edilir (Nisizawa, 1987).

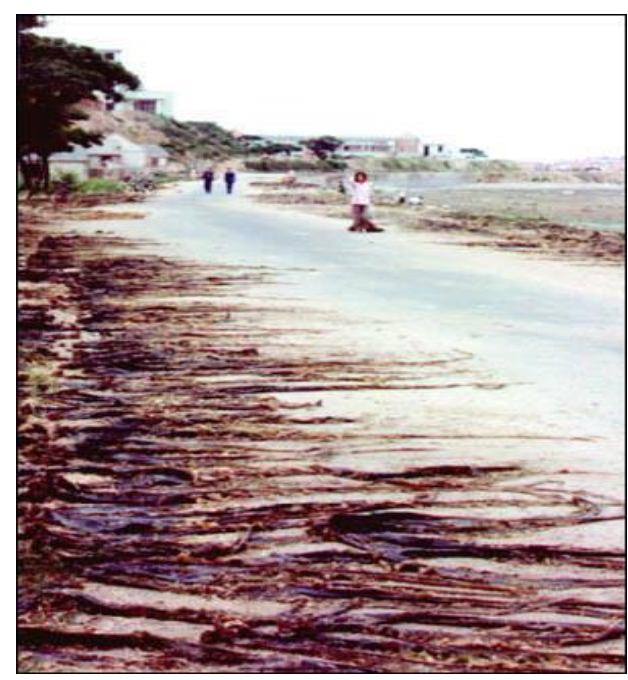

Şekil 6. Laminaria japonica'nın güneşte kurutulması (Nisizawa, 1987) Figure 6. Drying of Laminaria japonica in the sun (Nisizawa, 1987)
Çin'de, haidai, özellikle kışın yeşil sebzelerden korkulan kuzeyde, mineral ve vitamin içeriği sebebiyle sağlıkı bir sebze olarak kabul edilmektedir. Genellikle diğer ingrediyenlerle birlikte çorbada pişirilir. Japonya'da ringa veya dilimlenmiş somonla servis edilen, terbiye edilmiş ve pişirilmiş kombu gibi günlük gıdalarda kullanıır (Şekil 7) (Nisizawa, 1987).

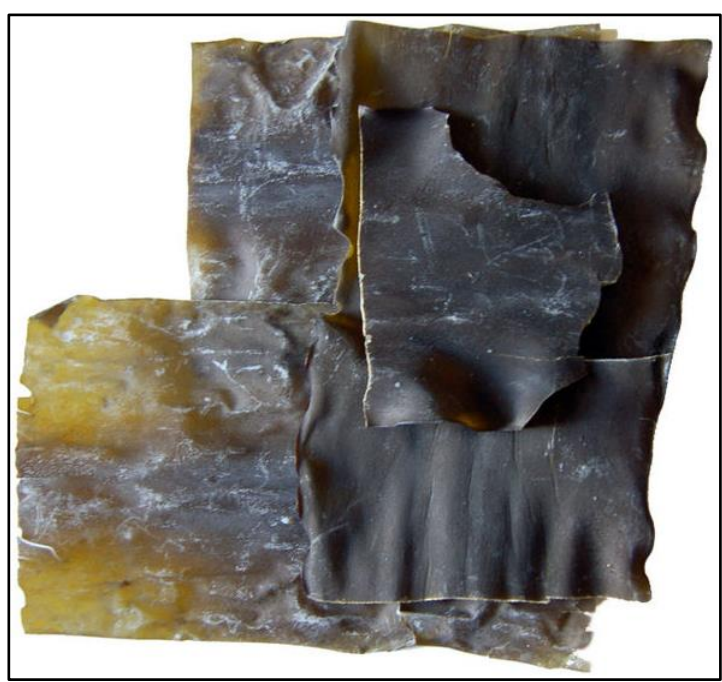

Sekil 7. Kombu tabakası (Anonim, 2015d) Figure 7. Kombu sheet (Anonim, 2015d) 
Suboshi kombu, koyu yeşil rengini vermesi için bir boyanın (malakit yeşili) kaynayan solüsyonu içerisine yerleştirilip muamele edilebilir, sonra kısmen kurutulur ve ardından bir rende ile rendelenir, buna aokombu veya yeşil kombu denmektedir (Nisizawa, 1987).

Tuzlanmış kombu yapımında, yüksek kaliteli suboshi kombu, kare parçalar ya da dikdörtgen parçalar halinde kesilir. Bunlar baharat veya soya sosu, mirin (bir çeşit tatı japon içkisi) ve şekerle suyun büyük çoğunluğu buharlaşıncaya kadar kaynatılır ve daha sonra kurutulur. Bu ürüne Shio kombu denir. Genel olarak Laminaria japonica'dan yapılmaktadır. Laminaria angustata'dan elde edilen suboshi kombu, soya sosuyla ve bazı baharatlarla kaynatıır. Kaynatma işlemi su tamamen buharlaşıncaya kadar devam eder ve tuzlu, sertimsi bir kombu ürünü elde edilir. Buna tsukudani kombu adı verilmektedir (Şekil 8) (Chapman ve Chapman, 1980).

Doğranmış kombu yapımında, suboshi kombu şeritler halinde doğranır ve soya sosuna batırılarak kombu turşusu elde edilir. Bu ürün genellikle doğranmış kuru mürekkep balığı ve ringa balığı ile karıştııılıktan sonra, soya sosu ile tatlandırılan Mitsumame kombu'ya benzer. Doğranmış kombuya ise Kizamı kombu denir (Chapman ve Chapman, 1980).

Dilimli kombu, Laminaria japonica'dan elde edilen suboshi kombunun, sirkeye batırılarak yumuşatılması ve bıçakla dilimlenmesi ile elde edilir. İnce geniş dilimler Oboro kombu adını alır. Yaprağın daha kalın ve açık sarımsı kalan orta kısmına Battera kombu denir (Chapman ve Chapman, 1980).

Rulo kombu, Laminaria angustata'dan ve Laminaria longissima'dan elde edilen suboshi kombunun dikdörtgenler halinde kesilip, kağıt rulo şeklinde sarılmasıdır. Daha sonra ürün kurutulmuş saptan yapılan ipe bağlandıktan sonra, soya sosu ve şekerden oluşan bir karışım ile kaynatıı. Ürüne kombumaki adı verilir (Chapman ve Chapman, 1980).

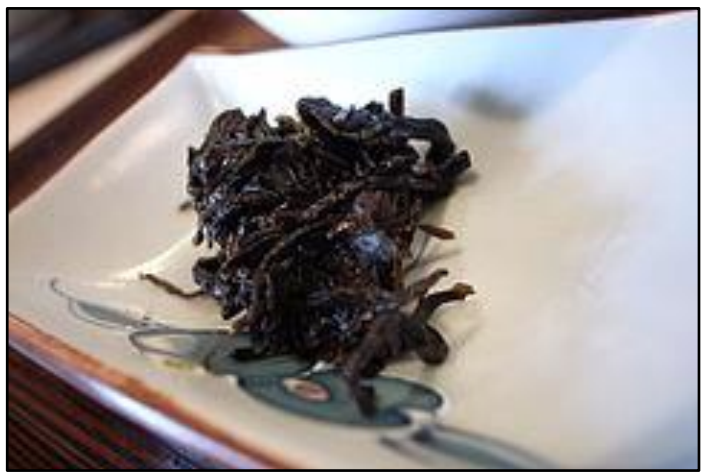

Şekil 8. Kombudan yapılan bir tsukudani tabağı (Anonim, 2015d) Figure 8. A dish of tsukudani made from kombu (Anonim, 2015d)

Yüksek kaliteli Laminaria japonica yaprakları sıcak hava ile kurutulup öğütülür. İstenirse az miktarda tuz veya şeker ilave edilebilir. Kombu çayı olarak tüketilir. Kombu reçel ve içki yapımında da kullanılmaktadır (Chapman ve Chapman, 1980).

Laminaria türü yaklaşık $\% 10$ protein, $\% 2$ yağ ve noridekinden daha düşük olsa da vitamin ve mineralleri de yararlı miktarda içermektedir. Örneğin; norideki vitamin ve niasin miktarının onda birine, B1 vitamini miktarının yarısına, fakat demir miktarının üç katına sahiptir. Kahverengi deniz yosunları nori ve diğer kırmızı deniz yosunlarında eksik olan iyotu da içermektedir (Nisizawa vd., 1987).

Kombu mineral, vitamin, aminoasit (özellikle askorbik asit ve glutamik asit) içeriği ve EPA (eikosapentaenoik asit) oranı (\%20-25) bakımından zengindir (Fujiwara vd., 1984).

Kombu umamiden sorumlu bir amino asit olan glutamik asidin iyi bir kaynağıdır. Çeşitli gıda maddelerinin kombu içerisine eklenmesi glutamik asiti veya glutamatları sağlamaktadır (Anonim, 2015d).

Suboshi kombu, çeşitli balık ezmeleri ve bitki kökleri ile birlikte pişirilmiş olarak satıır, ayrıca çorbası yapılır. Kombumaki, kurutulmuş ringa ya da dilimlenmiş somon balığı ile birlikte pişirilir. Baharatlanmış ve dilimlenmiş kombu suşide kullanılır. Ayrıca kombu tozu buğday unu ile karıştırılarak, tabletler ve yuvarlak tanecikler şeklinde satıır (Nisizawa, 1987).

Wakame, quandai-cai (Undaria pinnatifida): Japonya'da wakame ürünleri çoğunlukla Undaria pinnatifida'dan yapılmaktadır (Şekil 9). Undaria pinnatifida Japonya, Kore Cumhuriyeti ve Çin'in ılıman bölgelerindeki kayalık kıyılarda ve koylarda oluşan kahverengi bir deniz yosunudur. Wakame yetiştiriciliği Fransa'da da yapıımaktadır (Nisizawa, 1987).

Wakame bir deniz sebzesi ya da yenilebilir deniz yosunudur. Wakame yaprakları yeşil ve hafif tatlı bir tada ve satenimsi tekstüre sahiptir. Yapraklar pişme sırasında genişleyebileceği için küçük parçalar halinde kesilmelidir (Anonim, 2015e).

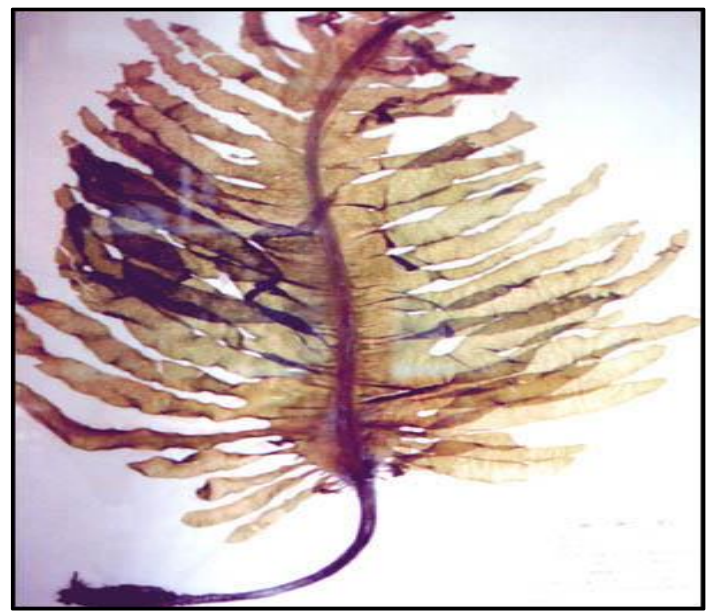

Şekil 9. Undaria pinnatifida, kuru numune (Çin) (Nisizawa, 1987)

Figure 9. Undaria pinnatifida, dried specimen (China) (Nisizawa, 1987)

Wakame hasat edildikten sonra deniz suyuyla, ardından içme suyuyla yıkanır, yaprağın merkezi orta damarı çıkarılır ve parçalar güneşte ya da sıcak havalı kurutucuda kurutulur, buna suboshi wakame denmektedir.

Ancak, çeşitli enzimler hala aktif olduğu için bu ürün depolama sırasında genellikle solmaktadır. Bunu bertaraf 
etmek için, taze wakamenin odun ya da saman külleriyle karıştııılı̆̆ı, 2-3 gün yere yayıldığı ve sonra karanlıktaki plastik poşetlere yerleştirildiği başka bir işlem uygulanır. Külün alkaliliği enzimleri inaktive etmektedir. Bitkiler önce deniz suyuyla, sonra tuzu ve külü uzaklaştırmak için içme suyuyla yıkanır, orta damarı çıkarılır ve parçalanıp kurutulur. Bu haiboshi wakame'dir ve derin yeşil rengini uzun bir süre muhafaza eder (Nisizawa, 1987).

Ağartılmış ve tuzlu wakame ana wakame ürünüdür. Taze wakame $80^{\circ} \mathrm{C}$ 'deki suyun içerisine $1 \mathrm{dk}$ daldırılır ve soğuk suda hızlı bir şekilde soğutulur. Her $100 \mathrm{~kg}$ deniz yosunu için yaklaşık $30 \mathrm{~kg}$ tuz karıştırılır ve 24 saat boyunca depolanır. Bu işlem wakameyi kurutur, fazla suyunu uzaklaştırır ve $-10{ }^{\circ} \mathrm{C}$ 'de depolanır. Paketlenmek için hazır olduğunda depodan alınır, orta damarları uzaklaştıııır ve parçalar satış için plastik poşetlere yerleştirilir. Bu ürün taze yeşil renklidir ve düşük sıcaklıklarda depolandığında uzun bir süre bu rengini korur (Nisizawa vd., 1987).

Japonya'da tuzlanan wakame suda bekletilerek hızlı bir şekilde tuzundan arındırılır, çeşitli çorbaların (özellikle miso çorbası) yapımında ve sulu yemeklerde kıvam arttırıcı olarak kullanılır. Ayrıca, taze olarak, soya sosu ile karıştırılarak çiğ salata (tofu salatası) şeklinde ya da haşlanarak üzerine sirke, şeker ve soya sosu eklenerek tüketilir (Şekil 10) (Nisizawa, 1987; Anonim, 2015e).

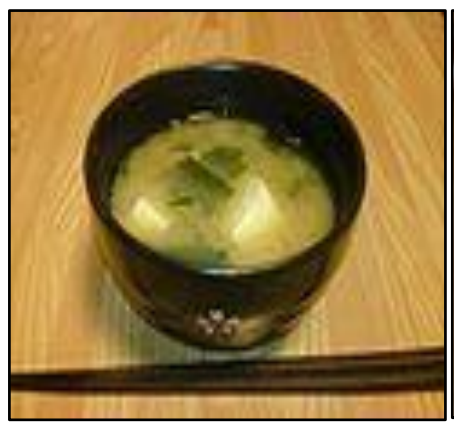

(a)

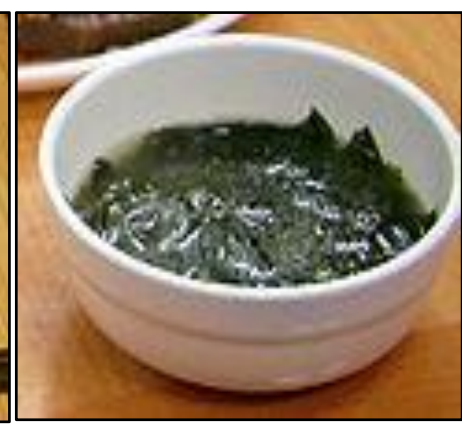

(b)

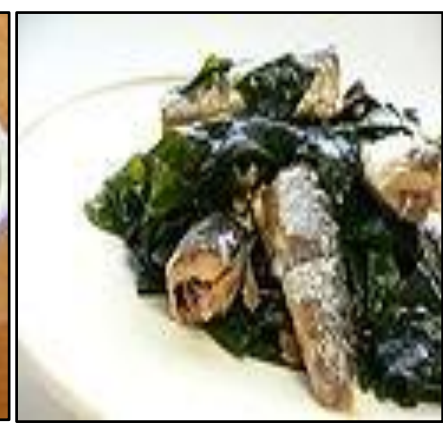

(c)

Şekil 10. a) Tofu, wakame ve scallion içeren Japon miso çorbası, b) Miyeok guk (wakameyle yapılan bir Kore çorbası), c) Sardalyalı wakameden oluşan bir Japon mezesi (Anonim, 2015e)

Figure 10. a) Japanese miso soup with tofu, wakame and scallion, b) Miyeok guk (a Korean soup made with wakame), c) A Japanese dish consisting of wakame with sardines (Anonim, 2015e)

Deniz yosunu salatası olarak da bilinen Goma wakame, Amerikan ve Avrupa suşi restaurantlarında popüler bir mezedir. Literatürde "susam deniz yosunu" anlamına gelmektedir ve susam tohumları gibi genellikle tarife dahil edilir (Anonim, 2015e).

Dilimlenmiş wakamede ise, yudoshi-enzo wakame, tuzunun akıtıması için tatı su ile yıkanır, santrifüj ile fazla suyu uzaklaştırılır, mekanik olarak küçük parçalara ayrılarak kurutucuda kurutulur. Kesilen yapraklar, üniform büyüklükte sınıflandırılarak plastik filmler içinde paketlenir ve satışa hazır hale getirilir (Yamanaka ve Akiyama, 1993).

Wakame, nori ve kombudan daha yüksek bir diyetsel lif içeriğine sahiptir. Diğer kahverengi deniz yosunları gibi yağ içeriği oldukça düşüktür. Açık havada kurutulmuş wakamenin vitamin içeriği yaş wakameninkiyle aynıdır ve $B$ grubu vitaminlerince, özellikle niasince nispeten zengindir, ancak işlenmiş wakame ürünleri vitaminlerinin çoğunu kaybetmektedir (Nisizawa, 1987).

Wakamede demir, magnezyum ve bakır miktarı, kombu ve hizikiye oranla daha fazladır. Kalsiyum ve fosfor içeriği, haiboshi ve dilimlenmiş wakamede nispeten yüksek, yudoshienzo wakamede ise, sodyum içeriği yüksektir. Amino asit içeriği açısından alanin, glisin, prolin ve serin miktarı, aspartik ve glutamik asite oranla daha fazladır. Söz konusu amino asitlerin varlığı wakamenin kendine özgü lezzetini oluşturur. Suboshi wakame, vitamin içeriği açısından zengin ve hemen hemen işlenmemiş yapraklardaki vitamin miktarına sahiptir, haiboshi wakame de nispeten vitamin açısından zengindir. Bununla birlikte diğer işlenmiş ürünlerde vitaminlerin önemli bir bölümü yok olmuştur. Kombu ve hizikiye zit olarak, wakamede toplam yağın yağ asiti içeriğinin önemli bir kısmını palmitik ve oleik asit oluşturur (Tablo 2) (Nisizawa, 1987).

Tablo 2. Çiğ wakame (100 g)'nin besin değeri (USDA, 2015)

Table 2. Nutritional value of wakame, raw (per $100 \mathrm{~g}$ ) (USDA, 2015)

\begin{tabular}{|l|l|}
\hline Enerji & $45 \mathrm{kcal}$ \\
\hline Karbonhidrat & $9.14 \mathrm{~g}$ \\
\hline Şekerler & $0.65 \mathrm{~g}$ \\
\hline Diyetsel lif & $0.5 \mathrm{~g}$ \\
\hline Yağ & $0.64 \mathrm{~g}$ \\
\hline Protein & $3.03 \mathrm{~g}$ \\
\hline Tiamin (B ${ }_{1}$ ) & $0.06 \mathrm{mg}$ \\
\hline Riboflavin (B $)$ & $0.23 \mathrm{mg}$ \\
\hline Niasin (B B $\left._{3}\right)$ & $1.6 \mathrm{mg}$ \\
\hline Pentotenik asit (B) & $0.697 \mathrm{mg}$ \\
\hline Folat (Bg) & $196 \mu \mathrm{g}$ \\
\hline Cvitamini & $3 \mathrm{mg}$ \\
\hline E vitamini & $1 \mathrm{mg}$ \\
\hline K vitamini & $5.3 \mu \mathrm{g}$ \\
\hline Kalsiyum & $150 \mathrm{mg}$ \\
\hline Demir & $2.18 \mathrm{mg}$ \\
\hline Magnezyum & $107 \mathrm{mg}$ \\
\hline Manganez & $1.4 \mathrm{mg}$ \\
\hline Fosfor & $80 \mathrm{mg}$ \\
\hline Sodyum & $872 \mathrm{mg}$ \\
\hline Çinko & $0.38 \mathrm{mg}$ \\
\hline
\end{tabular}


Hiziki (Hizikia fusiformis): Hiziki, Japonya'da insan besini olarak kullanılan makroalglerden elde edilen tipik bir besin maddesidir ve Hizikia fusiformis'ten yapılır. Hizikia fusiformis wakame ve kombudan daha ince bir yaprak yapısına sahip olan kahverengi deniz yosunudur (Şekil 11). Japonya'da doğal olarak toplanmakta ve Kore Cumhuriyeti'nde yetiştiriciliğ yapılmaktadır. Kore Cumhuriyeti'ndeki üretimin yaklaşık \%90'। işlenmekte ve Japonya'ya ihraç edilmektedir (Nisizawa, 1987).

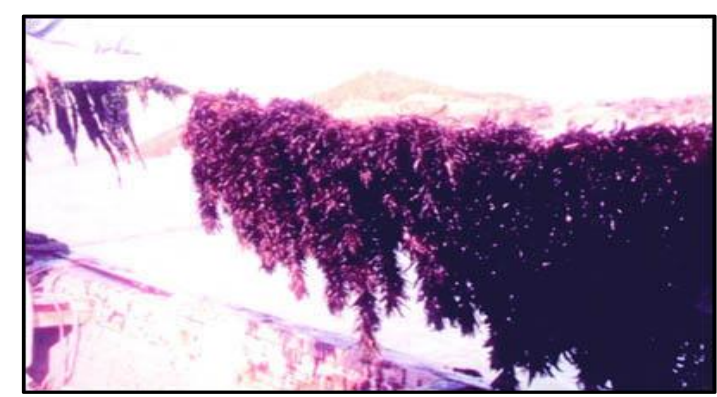

Şekil 11. Hizikia fusiformis (yetiştirilmiş olgun bitkiler) (Sohn, 1998) Figure 11. Hizikia fusiformis (mature plants from cultivation) (Sohn, 1998)

Hasat edildikten sonra, deniz suyuyla yıkanır (Şekil 12) ve güneşte kurutularak (Şekil 13) suboshi hiziki elde edilir. Güneşte kurutulmuş hiziki yerel kooperatiflerden toplanır ve daha sonra işleyecek firmalara satacak olan toptancılara açık arttırma ile satılır (Nisizawa, 1987).

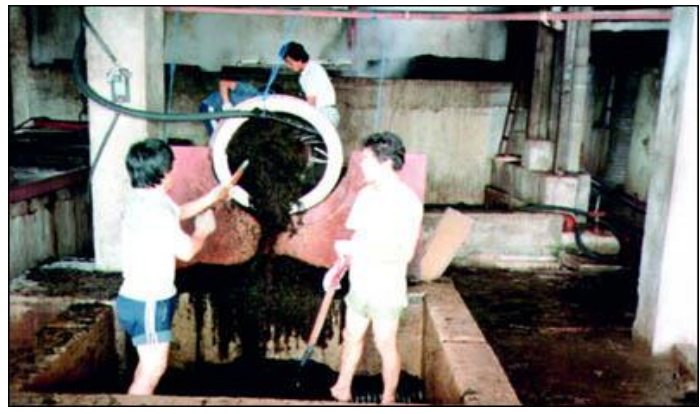

Şekil 12. Hizikia fusiformis'in yıkanması (Cheju Adası, Kore Cumhuriyeti) (Nisizawa, 1987)

Figure 12. Washing Hizikia fusiformis (Cheju Island, the Republic of Korea) (Nisizawa, 1987)

Ancak bu ürün, buruk bir tadı olmasından dolayı, doğrudan besin maddesi olarak kullanılmaz (Nisizawa, 1987). Hiziki çok koyu renklidir ve büzücü ve acı bir tat veren florotannin pigmentini olağan miktarından daha yüksek miktarda içerdiğinden işlemenin ilk aşamasında hiziki miktarının 1/10'u kadar başka kahverengi deniz yosunu (Eisenia bicyclis veya Ecklonia cava) eklenip 4-5 saat suda kaynatılır. Kaynatma işlemi bazı pigmentlerin hizikiden uzaklaştırır ve Eisenia veya Ecklonia eklemenin rengi yerine getirdiği bulunmuştur. Kaynatmadan sonra, deniz yosunu florotanninin uzaklaştıııması için 4-5 saat buharda pişirilir. Haşlanan hiziki küçük parçalar halinde (yaklaşık $5 \mathrm{~cm}$ ) kesilir ve tekrar güneşte kurutulur. Bu ürüne hoshi hiziki denir (Sohn, 1998).

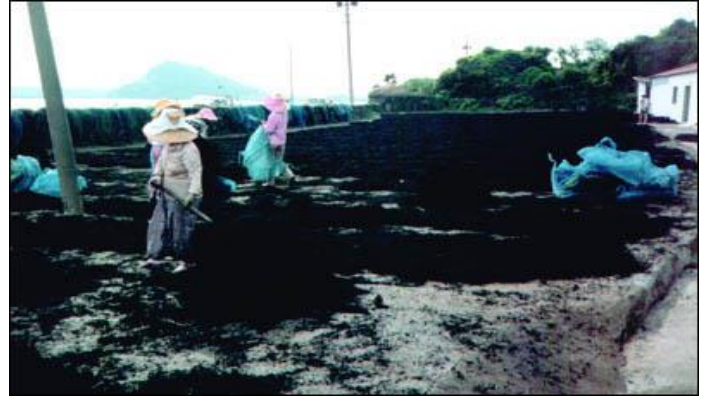

Şekil 13. Güneşte kurutulan Hizikia fusiformis (Cheju Adası, Kore Cumhuriyeti) (Nisizawa, 1987)

Figure 13. Sun drying Hizikia fusiformis (Cheju Island, the Republic of Korea) (Nisizawa, 1987)

Hoshi hiziki, haşlanmış ya da yağda kavrulmuş ve püre haline getirilmiş soya fasulyesi ve bazı sebzelerle, özellikle havuç ile karıştırılıp, soya sosu ve şekerle tatlandırılarak pişirilir ve satışa sunulur. Buğday unu ile karıştırılan hoshi hiziki tozu olarak piyasada da mevcuttur. Diğer bir kullanım alanı ise, hoshi hizikinin suda haşlanmasıyla elde edilen ve dashi adı verilen suyun, yemek ya da çorba yapımında kullanılmasıdır. Ayrıca, hoshi hiziki, soya sosu, şeker ve pirinç şarabı ilavesiyle haşlanır ve bu karışım haşlanmış pirinç ile birlikte servis edilir (Şekil 14) (Nisizawa, 1987).

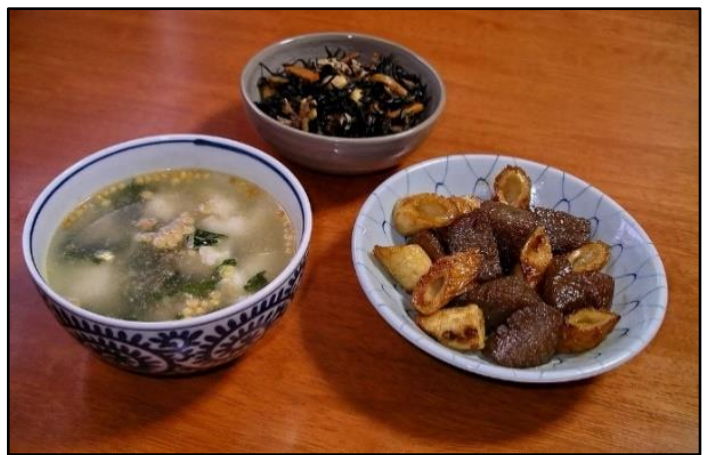

Şekil 14. Chazuke (solda) ve chikuwa (sağda) ile kaynatılmış hiziki (üstte) (Anonim, 2015f)

Figure 14. Simmered hijiki (top) with chazuke (left) and chikuwa (right) (Anonim, 2015f)

Vitaminlerin çoğu çiğ deniz yosununun işlenmesi sırasında tahrip olmasına rağmen; protein, yağ, karbonhidrat ve vitamin içeriği, bunların kombudaki miktarları ile benzerdir. Demir, bakır ve manganez içerikleri nispeten yüksek, kombudan kesinlikle daha yüksektir. Birçok kahverengi denzi yosunu gibi, yağ içeriği düşüktür (\%1.5), fakat yağ asitlerinden \%20-25'i eikosapentaenoik asit (EPA)'tir (Nisizawa, 1987; Nisizawa vd., 1987).

Mozuku (Cladosiphon okamuranus): Mozuku (Cladosiphon okamuranus) Japonya'nın güney adasının daha tropikal iklime sahip doğal populasyonundan hasat edilen kahverengi bir deniz yosunudur (Kagoshima ve Okinawa Vilayetleri) (McHugh, 2003). 
Hasat edilen deniz yosunlarının güneşten korunması gerekir. Piyasa için işlenmesi, temizleme ve \%20-25 tuzla tuzlanmasını içermektedir. Yaklaşık 15 gün boyunca kuruması için depolanır, süzülür ve $250 \mathrm{~g}$ ve $18 \mathrm{~kg}$ arasında değişen paketlerde ıslak, tuzlu halde satılır. Tuzunu uzaklaştırmak için yıkanır, taze bir sebze olarak kullanılır, soya sosu ile ve deniz yosunu salatasında yenir (Şekil 15) (McHugh, 2003).

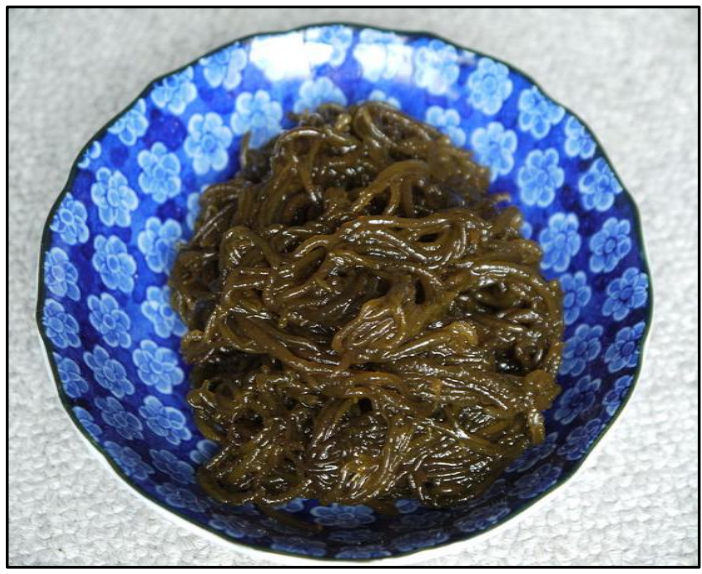

Şekil 15. Japon mozuku tabağı (Anonim, 2015g) Figure 15. Japanese mozuku dish (Anonim, 2015g)

Mozukunun bir çoğu halk tarafından yetiştirilmekte ve işleme fabrikalarına satılmaktadır. Mozukunun temel kullanımı gıda olarak ve Fukoidan olarak isimlendirilen sülfatlanmış polisakkaritlerin bir tipinin kaynağı olarak sağlık takviyelerine yardım ederek kanser tedavisinde kullanılmasıdır (Anonim, 2015g).

Deniz üzümü veya yeşil havyar (Caulerpa lentillifera): Caulerpa cinsinin birçok türü vardır, fakat Caulerpa lentillifera (Şekil 16) ve C. racemosa en popüler yenilebilir olanlarıdır. Her ikisi de üzüm benzeri görünüme sahip ve taze salata olarak kullanılmaktadır. Mactan Adası, merkezi Filipinler ve Cebu'daki C. lentillifera gölet yetiştiriciliği, Cebu ve Manila'daki pazarlarla ve Japonya'ya bazı ihracatlarla çok başarılıdır (McHugh, 2003).

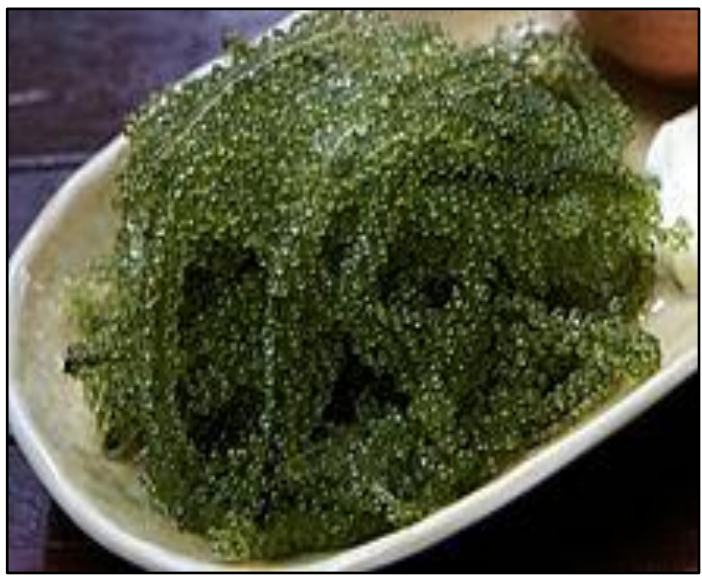

Şekil 16. Caulerpa lentillifera (Filipinler) (Anonim, 2015h) Figure 16. Caulerpa lentillifera (the Philippines) (Anonim, 2015h)
Hasat edilen bitkiler kumu ve çamuru uzaklaştırmak için deniz suyu aracılığıyla yıkanır, sonra gözden geçirilir, sıralanır ve 100-200 g şeklinde paketlere yerleştirilir. Bunlar soğutulursa ve nemli tutulursa 7 gün boyunca taze kalırlar. Yerel tüketim için veya Metro Manila'ya hava yoluyla taşınmada deniz yosunu muz yaprakları ile kaplı sepetlere dodurulur. 20-30 kg deniz yosunu yaprakların üzerine yerleştirilir, sepetin üstü daha çok muz yaprağı ile kaplanır ve sepete sabitlenecek plastik bir torba ile kapatılır (McHugh, 2003).

C. lentillifera Okinawa'da da yenmekte ve umi-budo olarak bilinmektedir (Şekil 17) (Anonim, 2015h).

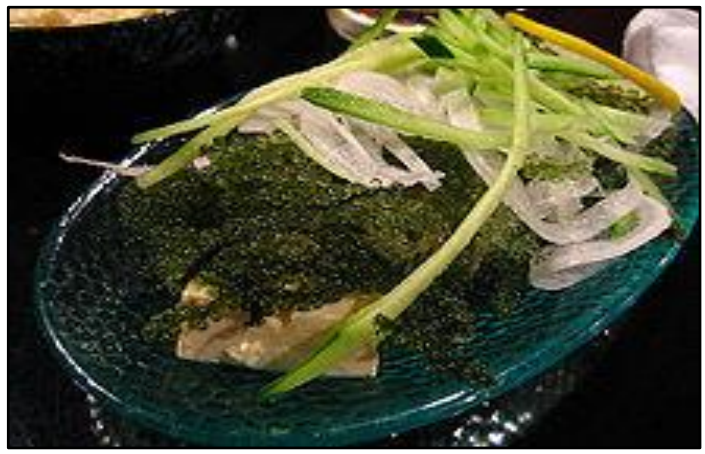

Şekil 17. Okinawa tarzı servis edilen umi-budo (Anonim, 2015h)

Figure 17. Umi-budo served Okinawan style (Anonim, 2015h)

Dulse (Palmaria palmata): Dulse, derimsi yapraklara sahip kırmızı bir algtir (Şekil 18). Çoğunlukla İrlanda'da ve doğu Kanada'daki Fundy Koyu'nun kıyısında hasat edilmektedir (McHugh, 2003).

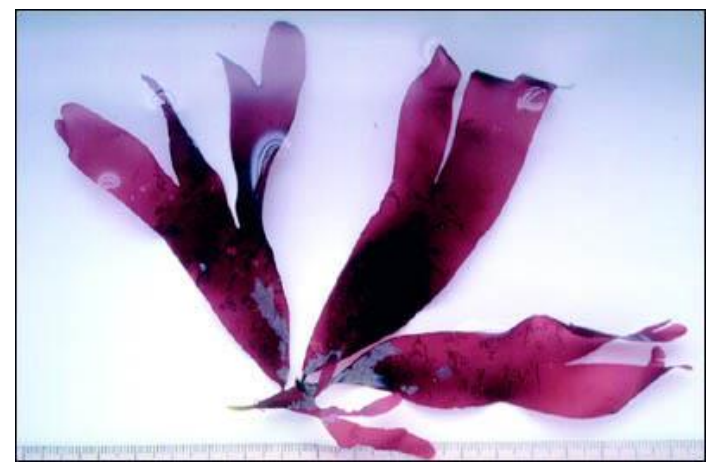

Şekil 18. Dulse, Palmaria palmata (Nisizawa, 1987)

Figure 18. Dulse, Palmaria palmata (Nisizawa, 1987)

Taze dulse kayalardan uzaklaştırılıp güneşte kurumadan önce doğrudan yenebilir (Anonim, 2015i). Toplandıktan sonra, deniz yosunu 6-8 saat güneşte kuruması için yere serilir. Eğer hava uygun değilse birkaç günlüğüne deniz suyunda depolanır, fakat çok geçmeden bozulabilir. Bütün dulse satış için, torba başına $50 \mathrm{~g}$ olacak şekilde, plastik poşetlere doldurulur. Daha alt kalitedeki dulse, genellikle zayıf kuruduğu için, pul haline veya baharat olarak kullanmak için toz haline getirilir, bazen mısır cipslerine eklenir. Nova Scotia ve Maine'de kurutulmuş dulse, tuzlu bir kokteyl atıştırmalığı ve susattığı için bar sahipleri 
tarafından genellikle ücretsiz olarak servis edilmektedir (Şekil 19) (McHugh, 2003). İzlanda'da gelenek, tereyağı ile birlikte yemektir. Çabucak tavada kızartılarak cips haline getirilir, peynirle, salsayla veya kaplanarak fırında pişirilir veya kısa bir süre mikrodalgada tutulur. Çorba, chowders, sandviç ve salatalarda kullanılır veya ekmek/pizza hamuruna eklenir. İnce doğranmış halde, et tabağında, chili gibi monosodyum glutamatın yerine tat geliştirici olarak kullanılmaktadır (Anonim, 2015i).

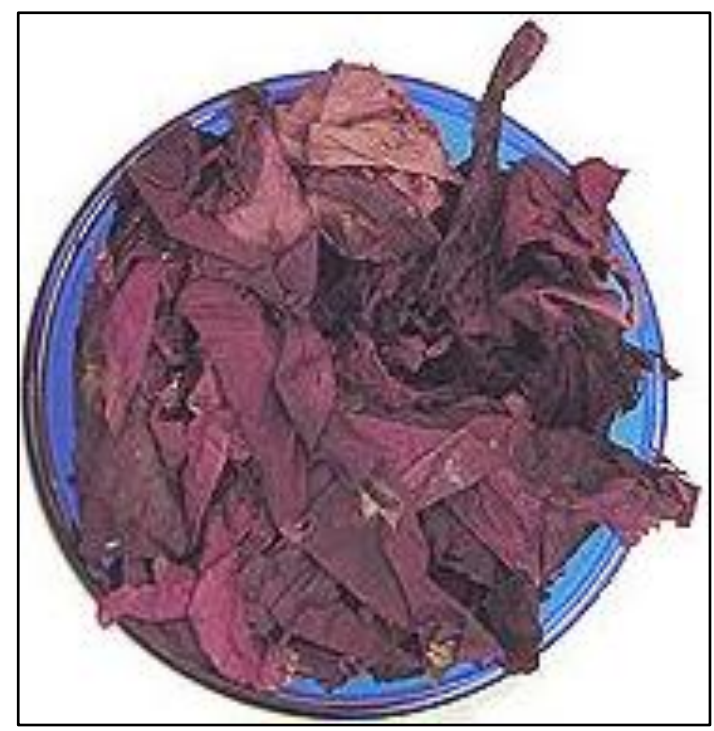

Şekil 19. Kurutulmuş dulse (Anonim, 2015i)

Figure 19. Dried dulse (Anonim, 2015i)

Dulse, genellikle İrlanda, İzlanda, Atlantik Kanada ve Kuzeydoğu Birleşik Devletler'de gıda ve ilaç olarak kullanılmaktadır. Birçok sağlıklı gıda mağazasında veya balık pazarlarında bulunmakta ve direkt olarak yerel distribitörlerden sipariş edilebilmektedir. Kuzey İrlanda'daki Ballycastle'da geleneksel olarak Ould Lammas Fuarı'nda satımaktadır. Özellikle Causeway Sahili boyunca popülerdir. Antrim İlçesi'nden Donegal İlçesi'ne kadar Ulster kıyı şeridi boyunca, atıştırmalıklar gibi kurutulmuş ve pişmemiş şekilde içki partilerinde yenir. Dulsenin özellikleri tat geliştiricilere benzediği için yemek pişirmede bu amaçla kullanılır. İrlanda'nın kuzey sahilinde genellikle "dillisk" olarak adlandırılır. Dillisk genellikle kurutulmakta ve Cezayir menekşesi satıcıları tarafından sahil kasabasındaki tezgahlarda atıştırmalık olarak satılmaktadır (Anonim, 2015i).

İrlanda'da ambalajlanmış halde satılan dulse, düz yapraklarının koyu kırmızı demetleri gibi görünmektedir. Tütün çiğneme gibi çiğ olarak yenmekte veya patates ile çorbada veya balık yemeklerinde pişirilmektedir (McHugh, 2003).

Dulse minerallerin iyi bir kaynağıdır, demir içeriği çok yüksektir ve insan beslenmesinde gerekli olan tüm iz elementleri içermektedir. Vitamin içeriği ıspanak gibi bir sebzeden bile daha yüksektir. Kanada'da bir şirket tanklar içinde yetiştirmekte ve ticari ismi "Deniz Maydonozu" ile bir deniz sebzesi olarak teşvik etmektedir. Bu normal dulse bitkilerinin bir çeşidi olan, fakat normalde düz bitkiden türemiş küçük süslü çıkıntılar şeklindedir (McHugh 2003). Dulse guatrı önleyen iyot içermektedir (Anonim, 2015i).

İrlandalı moss veya karragenan moss (Chondrus crispus): İrlandalı moss'un İrlanda'daki ve Avrupa'nın bir kısmındaki gıdalarda kullanımı uzun bir tarihe sahiptir. Bu yosun olduğu gibi yenmez, fakat karragenan içeriğinin bir sonucu olarak, suda kaynatıldığında koyulaştırıcı gücü için kullanılır. Geleneksel bir vanilya aromalı puding olan blancmange yapımında kullanıması buna bir örnektir. Doğu Kanada'da bir şirket Chondrus crispus'un bir suşunu yetiştirmekte ve Japonya'ya, diğer geleneksel Japon deniz yosunlarına benzeyen sarı bir deniz yosunu olan, "hana nori" olarak pazarlamaktadır. Japon pazarına ilk olarak 1996 yılında girmiş olan kuru ürünün, kullanıcılar tarafından yeniden yapılandırılmasıyla, 1999'un sonunda iyi bir satış elde ettiği kaydedilmiştir. Bu yosun deniz yosunu salatasında, saşimi garnitürleri ve bir çorba ingrediyeni olarak kullanılmaktadır (Şekil 20) (McHugh, 2003).

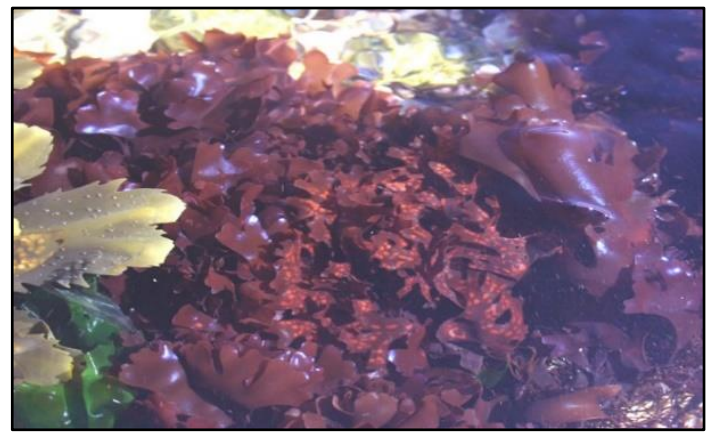

Şekil 20. Chondrus crispus (Anonim, 2015k)

Figure 20. Chondrus crispus (Anonim, 2015k)

Chondrus crispus genellikle dondurma gibi süt ürünlerinde ve öğle yemeği etini içeren işlenmiş gıdalarda kalınlaştırıcı ve stabilizör olarak kullanılan karragenanın endüstriyel bir kaynağıdır. Avrupa'da E407 veya E407b olarak belirtilmektedir. Ayrıca, basma kumaşta bir koyultma maddesi olarak ve bira veya şarapta durultma için kullanılabilmektedir. İrlandalı moss sıklıkla Mastocarpus stellatus (Gigartina mammillosa), Chondracanthus acicularis ( $G$. acicularis) ve büyümede ilişkili olduğu diğer deniz yosunlarıyla karıştırımaktadır. Karragenan ve agar-agar Asya'da badem jeli gibi jelatin benzeri tatılıar için de kullanımaktadır. Halen karragenanın en önemli kaynağı Kappaphycus ve Eucheuma cinslerinin tropikal deniz yosunlarıdır (Bixler ve Porse, 2011).

İskoçya bölgelerinde (İskoçya Gal bölgesindeki Cairgean olarak bilinen bölgede) ve İrlanda'da, önce vanilya, tarçın, brandi veya viski gibi diğer tatlandırıcılar ve şeker eklenip sütte kaynatılır ve süzülür. Son ürün pannacotta, tabyoka veya blancmange benzeri jölenin bir türüdür. Aynı şekilde Jamaika, Trinidad ve Tobago'da afrodizyak olduğuna inanılan, İrlandalı moss denilen yoğun bir içki yapmak için Glacilaria spp. tarçın ve sütle kaynatılır. Venezuela'da boğaz ağrısı ve göğüs tıkanıklığı için ev tedavisi olarak sütte kaynatılıp yatmadan önce 
balla içilerek kullanılmaktadır. İrlandalı moss genellikle bira işlemede, özellikle ev birasında durultma ajanı olarak kullanılmaktadır. Proteinleri ve diğer katıları çekerek küçük bir miktar bira mayası ile katnatıır, daha sonra soğutmanın ardından karışımdan uzaklaştıııı (Tablo 3) (Mitchell, 2011).

Tablo 3. İrlandalı moss (100 g)'un besin değeri (USDA, 2015) Table 3. Nutritional value of Irish moss (per $100 \mathrm{~g}$ ) (USDA, 2015)

\begin{tabular}{|l|l|}
\hline Enerji & $49 \mathrm{kcal}$ \\
\hline Karbonhidrat & $12.29 \mathrm{~g}$ \\
\hline Şekerler & $0.61 \mathrm{~g}$ \\
\hline Diyetsel lif & $1.3 \mathrm{~g}$ \\
\hline Yağ & $0.16 \mathrm{~g}$ \\
\hline Protein & $1.51 \mathrm{~g}$ \\
\hline Riboflavin $\left(\mathrm{B}_{2}\right)$ & $0.446 \mathrm{mg}$ \\
\hline Niasin $\left(\mathrm{B}_{3}\right)$ & $0.593 \mathrm{mg}$ \\
\hline Pentotenik asit ( $\left.\mathrm{B}_{5}\right)$ & $0.176 \mathrm{mg}$ \\
\hline B $_{6}$ vitamini & $0.069 \mathrm{mg}$ \\
\hline Folat (Bg) & $182 \mathrm{\mu g}$ \\
\hline C vitamini & $3 \mathrm{mg}$ \\
\hline Evitamini & $0.87 \mathrm{mg}$ \\
\hline K vitamini & $5 \mu \mathrm{g}$ \\
\hline Kalsiyum & $72 \mathrm{mg}$ \\
\hline Demir & $8.9 \mathrm{mg}$ \\
\hline Magnezyum & $144 \mathrm{mg}$ \\
\hline Manganez & $0.37 \mathrm{mg}$ \\
\hline Fosfor & $157 \mathrm{mg}$ \\
\hline Sodyum & $61 \mathrm{mg}$ \\
\hline Çinko & $1.95 \mathrm{mg}$ \\
\hline
\end{tabular}

Kanatlı kelpi (Alaria esculenta): Bu büyük kahvereng kelp İrlanda, Iskoçya (Birleşik Krallık), İzlanda, Brittany (Fransa), Norveç, Nova Scotia (Kanada), Sakhalin (Rusya) ve kuzey Hokkaido (Japonya) gibi bölgelerde bulunmaktadır. İrlanda'da, İskoçya (Birleşik Krallık)'da ve İzlanda'da hem taze hem de pişmiş olarak yenmektedir. Kelpler arasında en iy proteine sahip olduğu ve iz metaller ve vitaminler, özellikle niasin açısından da zengin olduğu söylenmektedir. Genellikle doğadan toplanmakta ve yerli halk tarafından yenilmektedir. Başarılı bir şekilde yetiştiriciliği yapıldığı halde ticari bir ölçekte henüz genişletilememiştir (McHugh, 2003).

Ogo, ogonori veya deniz moss (Gracilaria spp.): Gracilaria Japon, Hawai ve Filipinli mutfağında gıda olarak kullanılmaktadır (Şekil 21) (Kyaw, 1981). Japon mutfağında ogonori veya ogo olarak isimlendirilir (Şekil 22). Filipinlerde gulaman olarak isimlendirilir ve gulaman da denilen jelatin yapmak için kullanılır (Davidson, 2003). Jamaika'da Irlanda moss olarak bilinir (Goreau ve Trench 2013).

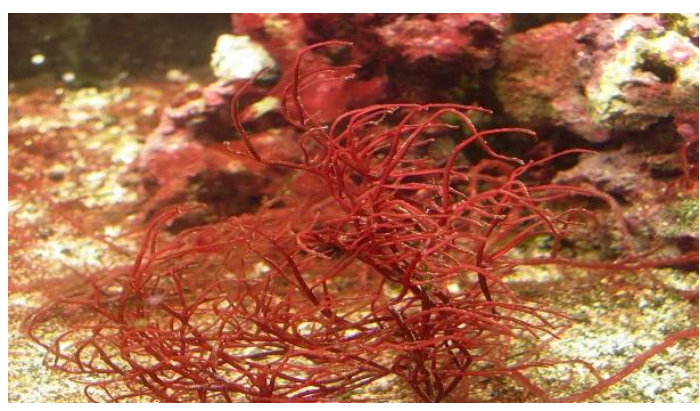

Şekil 21. Gracilaria (Anonim, 2015m) Figure 21. Gracilaria (Anonim, 2015m)
Taze Gracilaria Hawai'de (Amerika Birleşik Devletleri) onlarca yıldır toplanmakta ve salata sebzesi olarak satılmaktadır. Hawai'deki etnik grupların karışımı (Hawaililer, Filipinliler, Koreliler, Japonlar, Çinliler) sıradışı bir talep oluşturmakta ve tedarik zaman zaman doğal kaynaklardan elde edilen stoklarla sınırı kalmaktadır (McHugh, 2003).

Hawai'de bir gazlı tank sistemi kullanılarak, haftada 6 ton taze ağırlıkla, başarıı bir şekilde yetiştiriciliği yapıımaktadır. Limu manauea ve Limu ogo her ikisi de taze sebze olarak satımaktadır, ikincisi genellikle çiğ balık ile karıştıııır. Endonezya, Malezya, Filipinler ve Viet Nam'da Gracilaria türleri kıyı insanları tarafından yiyecek için toplanmaktadır. Tayland'ın güneyinde, insanlara ekstrakte edilmiş agarın kullanıması ve kaynatılmasıyla nasıl jöleler yapabileceklerini gösteren bir eğitim programı gerçekleştirilmiştir. Kuzey Hint Adaları'nda, Gracilaria marketlerde deniz moss olarak satımaktadır. Afrodizyak özelliklere sahip olmasıyla ünlüdür ve alkolsüz bir içecekte temel madde olarak kullanımaktadır. Bu amaçla St Lucia ve komşu adalarda başarılı bir şekilde yetiştiriciliği yapılmaktadır (McHugh, 2003).

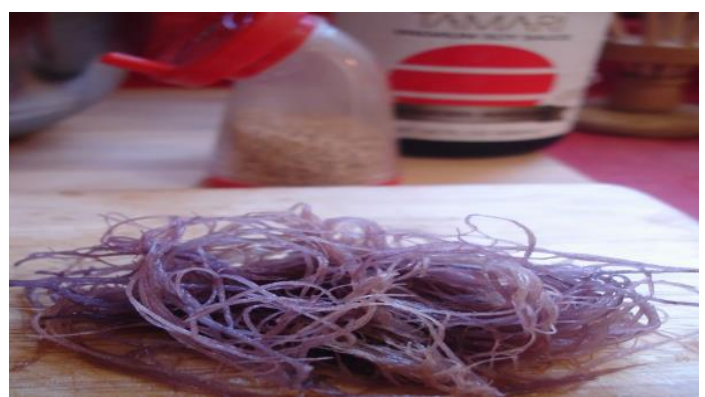

Şekil 22. Ogonori (Anonim, 2015m)

Figure 22. Ogonori (Anonim, 2015m)

Agar taşıyan Glacilaria sp. polisakkaritlerinden agaraz dijestiyonu ile hazırlanan polimerizasyon 6 dereceli Gracilaria oligosakkaritlerinin Japon ensefalit viral enfeksiyona karşı in vitro ve in vivo denemeler sırasında etkin bir profilaktik ajan olduğu gösterilmiştir. Glacilaria sp.'nin sülfatlanmış oligosakkaritleri antiviral ajan olarak daha da geliştirilmesi için ümit verici bir aday olarak gözükmektedir (Kazlowski vd., 2012).

Callophyllis variegata: Şili'de yenilebilir deniz yosunları talebi artmıştır ve Callophyllis variegata ("carola") en popülerlerinden birisidir. Tüketimi 1995 yılında sıfırken; 1999 'da 84 yaş tona yükselmiştir. Bu kırmızı deniz yosunu yüksek bir ticari değere sahiptir, fakat biyolojisine ait bilgiler sınırıdır. 1997'de doğal kaynakların ve yetiştiricilik fırsatlarının yönetimi için önerilerle sonuçlanması gereken yeni bir araştırma projesi finanse edilmiştir (McHugh, 2003). 


\section{KAYNAKÇA}

Anonim. (2015a). Laver (seaweed)

http://en.wikipedia.org/wiki/Laver_(seaweed) (15.01.2015).

Anonim. (2015b). Nori. http://en.wikipedia.org/wiki/Nori (15.01.2015).

Anonim. (2015c). Sea lettuce. http://en.wikipedia.org/wiki/Sea_lettuce (15.01.2015).

Anonim. (2015d). Kombu. http://en.wikipedia.org/wiki/Kombu (15.01.2015).

Anonim. (2015e). Wakame. http://en.wikipedia.org/wiki/Wakame (15.01.2015)

Anonim. (2015f). Hijiki. http://en.wikipedia.org/wiki/Hijiki (15.01.2015).

Anonim. (2015g). Cladosiphon okamuranus.

http://en.wikipedia.org/wiki/Cladosiphon_okamuranus (15.01.2015).

Anonim. (2015h). Caulerpa lentillifera.

http://en.wikipedia.org/wiki/Caulerpa_lentillifera (15.01.2015).

Anonim. (2015i). Palmaria palmata.

http://en.wikipedia.org/wiki/Palmaria_palmata (15.01.2015).

Anonim. (2015k). Chondrus crispus.

http://en.wikipedia.org/wiki/Chondrus_crispus (15.01.2015).

Anonim. (2015m). Gracilaria. http://en.wikipedia.org/wiki/Gracilaria (15.01.2015).

Arasaki S. \& Arasaki T. (1983). Low calorie, high nutrition vegetables from the sea to help look and feel better. Japan Publications, Tokyo, $196 \mathrm{p}$.

Atay, D. (1978). Deniz yosunları ve değerlendirme araçları. Ankara Üniversitesi Ziraat Fakültesi Yayınları, Başbakanlık Basımevi, Ankara, 128s.

Atay, D. (1984). Bitkisel akuakültür ve üretim tekniği. Ankara Üniversitesi Ziraat Fakültesi Yayınları, Ankara, $203 \mathrm{~s}$

Bilgin, Ş., \& Ertan, Ö.O. (2002). Selected chemical constituents and their seasonal variations in Flabella petiolata (Turra) Nizam. and Halimeda tuna (Ellis\&Sol.) J.V. Lamour. in the Gulf of Antalya (North-eastern Mediterranean). Turkish Journal of Botany, 26(2): 87-90.

Bixler, H.J., \& Porse, H. (2011). A decade of change in the seaweed hydrocolloids industry. Journal of Applied Phycology, 23(3): 321-335. doi: 10.1007/s10811-010-9529-3

Chandini, S.K., Ganesan, P., Suresh, P.V., \& Bhaskar, N. (2008). Seaweeds as a source of nutritionally benefical compounds-a review. Journal of Food Science and Technology, 45(1): 1-13.

Chapman, V.J., \& Chapman, D.J. (1980). Seaweeds and their uses. Chapman \& Hall, London, 334 p. doi: 10.1007/978-94-009-5806-7

Cirik, Ş. (1981). Türk denizlerindeki algler ve değerlendirme araçları. Çevre Haberleri, 9: 65-68

Çetingül, V., \& Güner, H. (1996). Ekonomik değerdeki bazı makroalglerin kimyasal içeriklerinin saptanması. Ege Journal of Fisheries and Aquatic Sciences, 13(1-2): 101-118.

Davidson A. (2003). Seafood of South-East Asia: A Comprehensive Guide with Recipes. Ten Speed Press, $368 \mathrm{p}$.

Dawczynski, C., Schubert, R., \& Jahreis, G. (2007). Amino acids, fatty acids and dietary fibre in edible seaweed products. Food Chemistry, 103(3): 891-899.

10.1016/j.foodchem.2006.09.041

doi:

Dere, S., Dalkıran, N., Karacaoğlu, D., Yıldız, G., \& Dere, E. (2003). The determination of total protein, total soluble carbonhydrate and pigment contents of some macroalgae collected from Gemlik-Karacaali (Bursa) and Erdek-Ormanlı (Balıkesir) in the Sea of Marmara, Turkey. Oceanologia, 45(3): 453-471.

Durmaz, Y., ışık, O., Bandarrra, N.M., Cirik, S., Turan, G., \& Gökpınar, Ş (2002). Porphyridium cruentum (Rhodophyceae) yağ asitler kompozisyonuna kurutma yöntemlerinin etkisi. Ege Journal of Fisheries and Aquatic Sciences, 19(1-2): 189-195.

Fleurence, J. (1999). Seaweed proteins: Biochemical, nutritional aspects and potential uses. Trends in Food Science and Technology, 10(1): 25-28. doi: 10.1016/S0924-2244(99)00015-1
Fujiwara, M., Lizima, N., Yamamoto, I., \& Nagumo, T. (1984). Purification and chemical and physical characterization of antitumour polysaccharide from the brown seaweed, Sargassum fulvellum. Carbonhydrate Research, 125(1): 97-106. doi: 10.1016/0008-6215(84)85145-9

Goreau, T.J., \& Trench, R.K. (2013). Innovative methods of marine ecosystem restoration. CRC Press, New York, $297 p$.

Gökpınar, S., Göksan, T., \& Durmaz, Y. (2001). PUFA kaynağı olarak mikroalgler, XI. Ulusal Su Ürünleri Sempozyumu, Hatay, 4-6 Eylül, Cilt II, s. $779-785$.

Güven, C.K., Zeybek, N., Cirik, Ş. (1991). 1899 ve 1990 yılları arasında Türk deniz yosunları üzerindeki çalıșmalar. İstanbul Üniversitesi, Deniz Bilimleri ve Coğrafya Enstitüsü Bülteni, (7): 51-58.

Jensen, A. (1966). Carotenoids of norwegian brown seaweeds and seaweed meals. Norwegian Institute of Seaweed Research, Report No: 31, 1-138.

Kaba, N., \& Çağlak, E. (2006). Deniz alglerinin insan beslenmesinde kullanımı. Ege Journal of Fisheries and Aquatic Sciences, 23(1/2): 243-246.

Kanazawa, A. (1963). Vitamins in algae. Bulletin of the Japanese Society of Scientific Fisheries, 29: 713-731. doi: 10.2331/suisan 29.713

Kaykaç, G.O., Cirik, Ş., \& Tekinay, A.A. (2008). Yeşil deniz alglerinden Ulva rigida (C., Agardh)'ın besin kompozisyonu ve aminoasit içeriklerinin mevsimsel değişimi. Ege Journal of Fisheries and Aquatic Sciences, 25(1): 9-12.

Kazlowski, B., Chiu, Y.H., Kazlowska, K., Pan, C.L., \& Wu, C.J. (2012). Prevention of Japanese encephalitis virus infections by low-degreepolymerisation sulfated saccharides from Gracilaria sp. and Monostroma nitidum. Food Chemistry, 133 (3): 866-74. doi: 10.1016/j.foodchem.2012.01.106

Kocataş, A. (2005). Oseanoloji. Ege Üniversitesi Basımevi, Bornova, İzmir, 357

Kyaw, A. (1983). The production of Gracilaria edulis in Burma. Report of the Training Course on Gracilaria Algae, Manila, Philippines, 1-30 April, p. 135-137.

McHugh, D.J. (2003). A guide to the seaweed industry. FAO Fisheries Technical Paper, No. 441, Rome, 105 p.

Mitchell, S.A. (2011). The Jamaican root tonics: a botanical reference. Focus on Alternative and Complementary Therapies, 16(4): 271-280. doi: 10.1111/j.2042-7166.2011.01124.x

Myklestad, S. (1963). Experiments with seaweed as supplemental fertilizer. Bergaman Press, London, pp. 432-438.

Nisizawa, K. (1987). Preparation and marketing of seaweeds as foods. Food and Agriculture Organization of the United Nations, pp. 147-189.

Nisizawa, K., Noda, H., Kikuchi, R., \& Watanabe, T. (1987). The main seaweed foods of Japan. Hydrobiologia, 151/152: 5-29. doi: $10.1007 / B F 00046102$

Noda, H. (1971). Biochemical studies on marine algae. 3. Relation between quality and inorganic constituents of asakusanori. Bulletin of the Japanese Society of Scientific Fisheries, 37(1): 35-39. doi: 10.2331/suisan.37.35

Noda, H., Horiguchi, Y., \& Araki, S. (1975). Studies on the flavor substances of nori, the dried laver Porphyra sp. 2. Free Amino Acids and 5'-nucleotides. Bulletin of the Japanese Society of Scientific Fisheries, 41: 1299-1303. doi: 10.2331/suisan.41.1299

Özdemir, N., \& Erkmen, J. (2013). Yenilenebilir biyoplastik üretiminde alglerin kullanımı. Karadeniz Fen Bilimleri Dergsisi, 3(8): 89-104.

Polat, S., \& Özoğul, Y. (2008). Biochemical composition of some red and brown macroalgae from the Northeastern Mediterranean Sea. International Jounal of Food Science and Nutrition, 59(7): 566-572. doi: 10.1080/09637480701446524

Polat, S., \& Özoğul, Y. (2009). Fatty acid, mineral and proximate composition of some seaweeds from the Northeastern Mediterranean coast. Italian Journal of Food Sciences, 21(3): 317-324.

Soeder, C.J. (1976). Zur verwendung von mikroalgen für ernährungszwecke. Naturwissenschaften, 63: 131-138. doi: 10.1007/BF00600487 
Sohn, C.H. (1998). The seaweed resources of Korea. In: Seaweed resources of the world. Japan International Cooperation Agency, Yokosuka, pp. 1533.

Tseng, C.K. (1981). Commercial cultivation [Algae]. In: Botanical monographs (USA), C.S. Lobban, M.J. Wyne (Ed.), Blackwell Science Publication, pp. 680-725.

USDA. (2015). USDA National Nutrient Database for Standard Reference Release 28. United States Department of Agricultural Research Service, Nutirient Data Laboratory. $\quad$ http://www.ars.usda.gov/ba/bhnrc/ndl (01.09.2015).

Wong, K.H., \& Cheung, P.C.K. (2000). Nutritional evaluation of some subtropical red and green seaweeds Part I-proximate composition. Amino acids profiles end some physico-chemical properties. Food Chemistry 71(4): 475-482. doi: 10.1016/S0308-8146(00)00175-8

Yamamoto, I. (1982). Antitumor activity of crude extracts from edible marine algae against L-1210 leukemia. Botanica Marina, 25(9): 455-457.

Yamanaka, R., \& Akiyama, K. (1993). Cultivation and utilization of Undaria pinnatifida (wakame) as food. Journal of Applied Phycology, 5(2): 249253. doi: $10.1007 / B F 00004026$

Zemke-White, L.W., \& Ohno, M., (1999). World seaweed utilization: end-of century summary. Journal of Applied Phycology, 11(4): 369-376. doi: 10.1023/A:1008197610793 